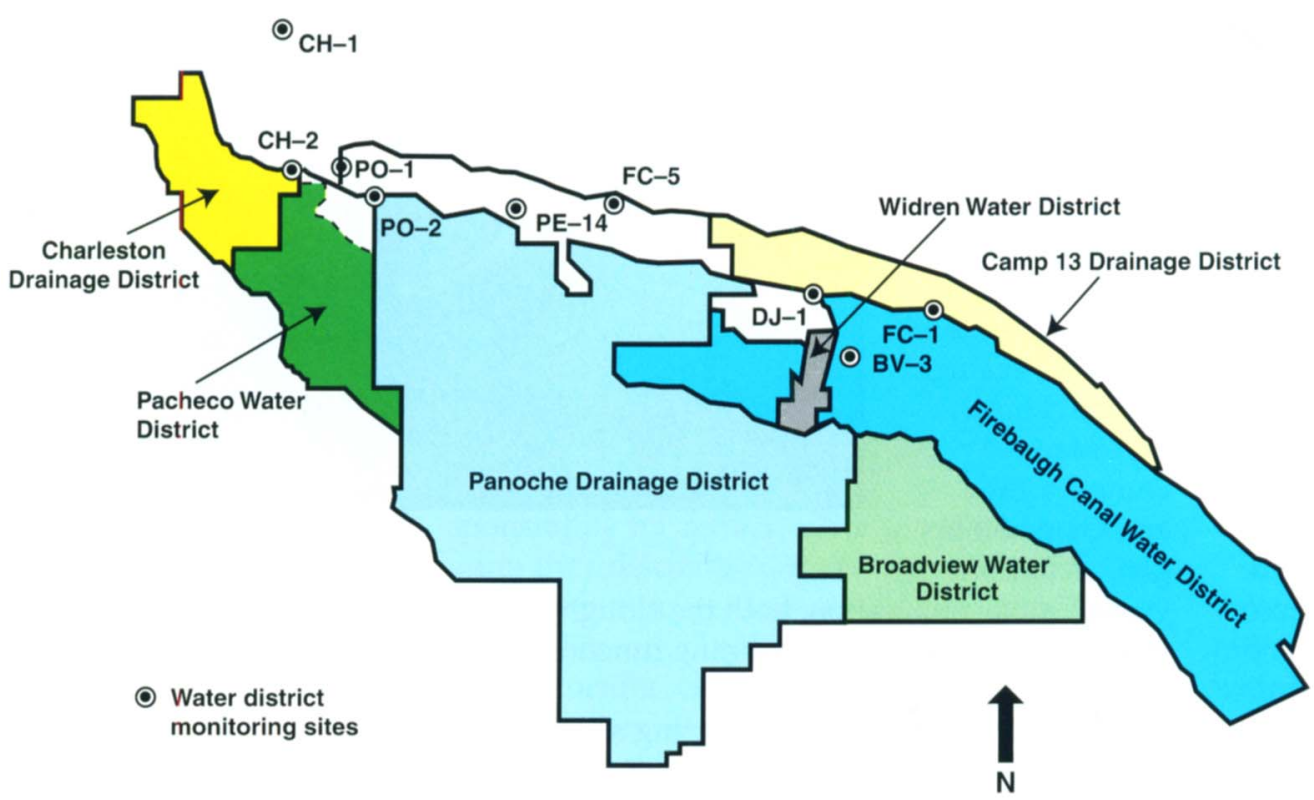

Fig. 1. Water districts shown in color are part of the Grasslands Bypass Project. The combined districts form a drainage area that appears as a yellow outline in figure 2 (page 13).

\title{
Innovative strategies reduce selenium in Grasslands drainage
}

Nigel W.T. Quinn \ Joseph C. McGahan J Michael L. Delamore

The Grasslands Bypass Project in the western San Joaquin Valley of California was conceived as a means of diverting seleniumcontaminated agricultural drainage water from fresh water channels serving Grassland wetlands. Use of the federally owned San Luis Drain was made contingent on the formation of a regional drainage management authority by the project proponents and compliance with strict monthly and annual selenium-load targets and agreement to strict monthly and annual selenium-load targets for discharges from the 97,000acre $(44,000$ hectares) project area. During the first year of this 5-year project, the Grasslands Basin farmers were successful in reducing selenium export from the project area by $44 \%$ and $33 \%$ when compared to water years 1995 and 1996. Although monthly targets were exceeded during the spring months of 1997, in part due to unusually high rainfall runoff from the project area and upper watershed, the goals of the project were met. There is popular sentiment that more was learned about selenium drainage management and achieved in selenium load reductions by participating water districts during the first year of the project than in the past decade.
The western San Joaquin Valley is arid and typically receives too little rainfall to make commercial agriculture viable without supplemental irrigation. When irrigation water is supplied without the provision of adequate drainage, the water table in irrigated areas tends to rise, leading to waterlogging and evapoconcentration of salts and trace elements in the crop root zone. Infiltrating irrigation water dissolves and leaches these salts and trace elements into the shallow groundwater, a necessary consequence of maintaining salt balance in the crop root zone. Where drainage is provided, it typically contains high concentrations of dissolved solids, selenium and boron. In the western San Joaquin Valley, most of the selenium. and boron load contained in drainage water originates from resident groundwater displaced into drainage tiles by infiltrating irrigation water. Groundwater concentrations of these salts and trace elements are considerably higher than the leachate concentrations.

The Grasslands Basin on the west side of the San Joaquin Valley has historically drained to the San Joaquin River and comprises six agricultural water districts (fig. 1); several federaland state-managed wildlife refuges; and the 50,000-acre (23,000 ha) Grassland Water District, which services mostly private duck clubs. Kesterson Reservoir was initially designed as a flow-regulating facility on the San Luis Drain for export of saline agricultural drainage from the west side of the San Joaquin Valley. However, after budgetary problems and planning conflicts resulted in the completion of only 84 miles $(135 \mathrm{~km})$ of the 163 -mile $(260 \mathrm{~km})$ salt-export facility, it opened in 1980 to function as a terminal evaporation facility. The drain provided drainage service to a 5,200-acre (2,363 ha) area in the Westlands Water District, located immediately south of the Grasslands Basin. Kesterson Reservoir was closed in 1986 when nesting failure and selenium-related birth defects were observed in resident wildfowl. Images of malformed duck embryos galvanized the environmental community and led the federal government to initiate two 5-year, multi- 
million-dollar research, monitoring and planning programs to remediate Kesterson Reservoir and to develop solutions to regional selenium drainage problems.

Resolution of the selenium crisis at Kesterson Reservoir led to the development of state San Joaquin River objectives for boron and selenium below the confluence of the Merced River (fig. 2, Crows Landing). Federal objectives for salinity below the confluence of the Stanislaus River (Vernalis, near Modesto) were developed to protect riparian agricultural diverters in the South Delta. A U.S Environmental Protection Agency selenium waterquality objective for receiving waters of $5 \mathrm{ppb}$ ( $2 \mathrm{ppb}$ for water supply to wetlands) was established based on toxicity to fish and wildlife species. A boron objective was set at $2 \mathrm{ppm}$ to protect agricultural productivity of downstream riparian diverters. A salinity objective of $1,000 \mu \mathrm{mhos} / \mathrm{cm}$ or 590 ppm total dissolved salts (TDS) (700 $\mu \mathrm{mhos} / \mathrm{cm}$ or 410 ppm during the irrigation season) was established at Vernalis. Salts and trace elements carried by the San Joaquin River into the Sacramento-San Joaquin Delta concern not only delta agricultural interests but also municipal and industrial water agencies that divert water from the Delta, including Southern California.

Assimilative capacity of the San Joaquin River is the amount of a contaminant that the river can accommodate, at a given discharge rate, without exceeding water-quality concentration objectives at the compliance monitoring point. The numeric concentration objectives for selenium, developed after lengthy review of available data and weeks of public hearings at the State Water Resources Control Board, are based on toxicity to fish. The results of continuing research into the bioavailability of selenium in the environment and the fate of selenium during transport from drainage sump to the San Joaquin River and Bay Delta may lead to changes in these concentration objectives.

\section{Grasslands Bypass Project}

Interim use of a 28-mile section of the San Luis Drain was approved as a

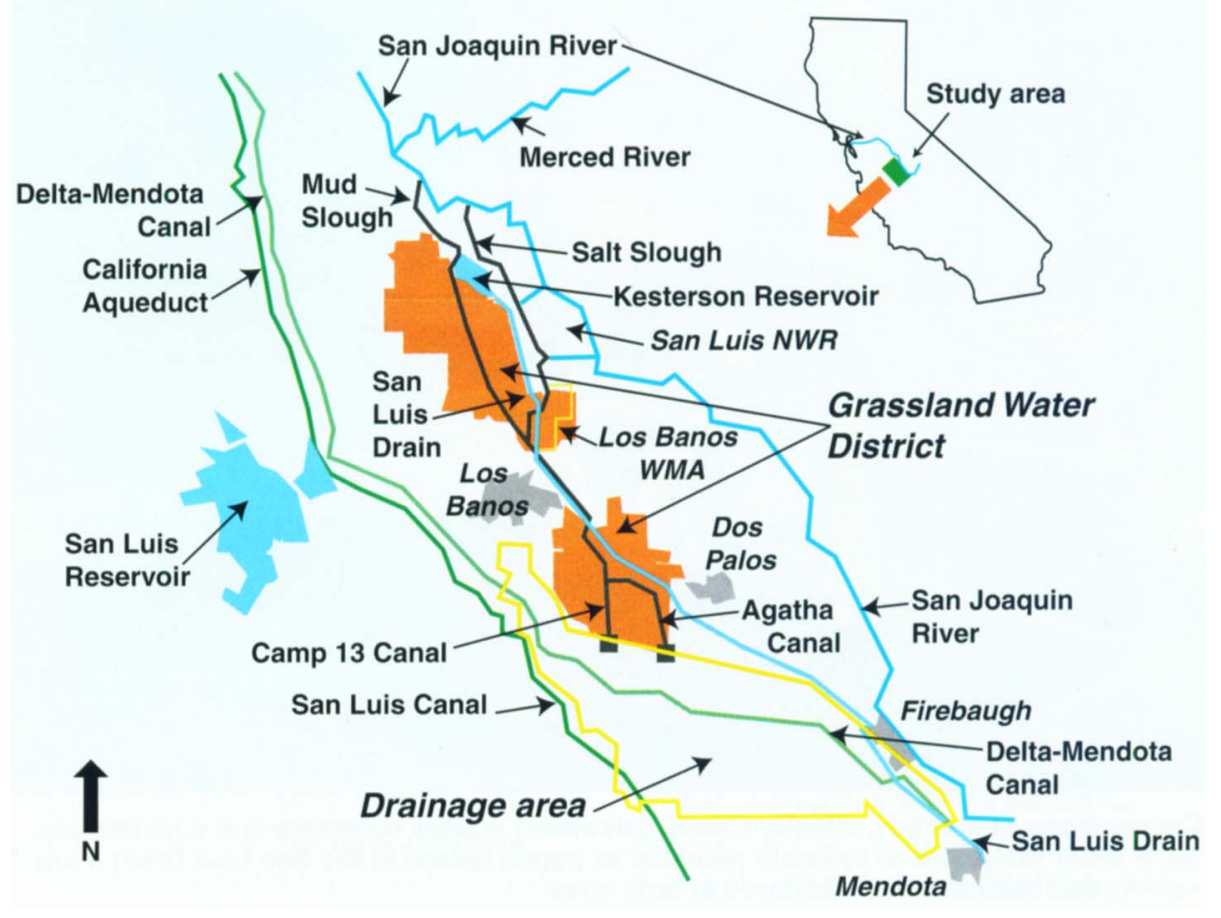

Fig. 2. San Joaquin River Basin and major tributaries.

first step toward alleviating chronic water-management problems for wildlife areas in the greater Grasslands Basin. Drainage water from agricultural districts previously entered the southern portion of the Grasslands Water District through either the Agatha Canal or the Camp 13 Canal (fig. 2). This flip-flop drainage conveyance system was in operation between 1985 and 1996, subject to an agreement between Grassland Water District and the agricultural districts, initiated when drainage water ceased to be used as a water supply for wetlands. Farther north, in the vicinity of the state-managed Los Banos Wildlife Management Area, the combined drain water from South Grasslands was diverted to Salt Slough, which discharges to the San Joaquin River (fig. 3). Although the system worked as an emergency response following the recognition of selenium concerns in 1985, it was highly inefficient and led to situations where wetlands were not able to receive deliveries because of the presence of drainage water in the conveyance system. Wetlands were advised under U.S. Fish and Wildlife Service guidelines not to accept water deliveries that contain more than 2 ppb sele-

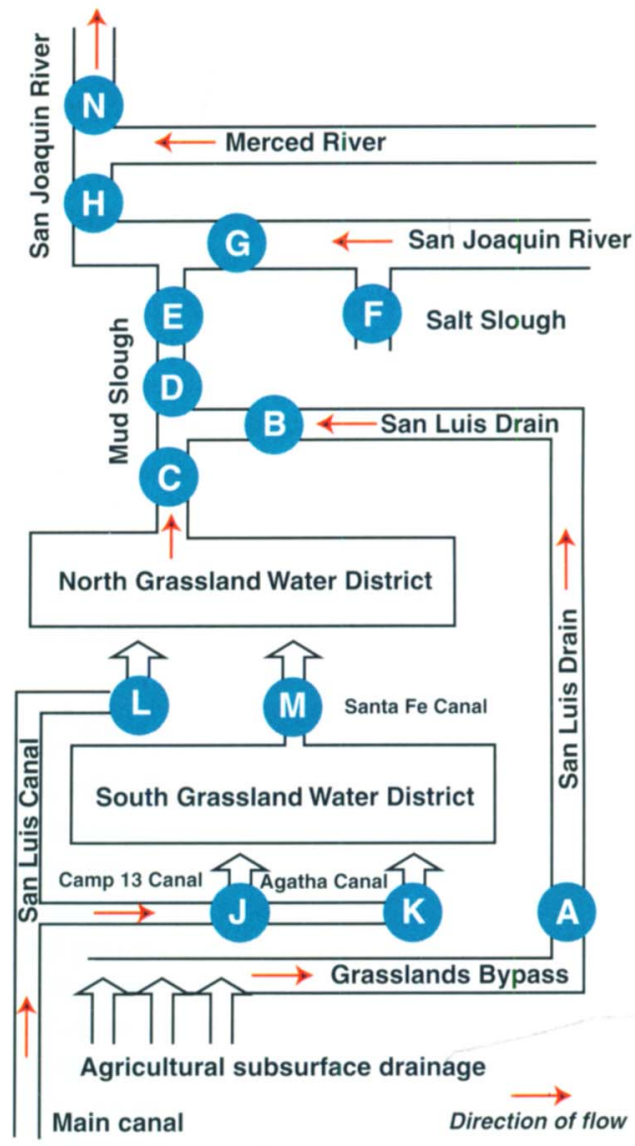

Fig. 3. Schematic diagram showing bypass of selenium drainage around the Grassland Water District. Project monitoring stations indicated by letters in circles. 


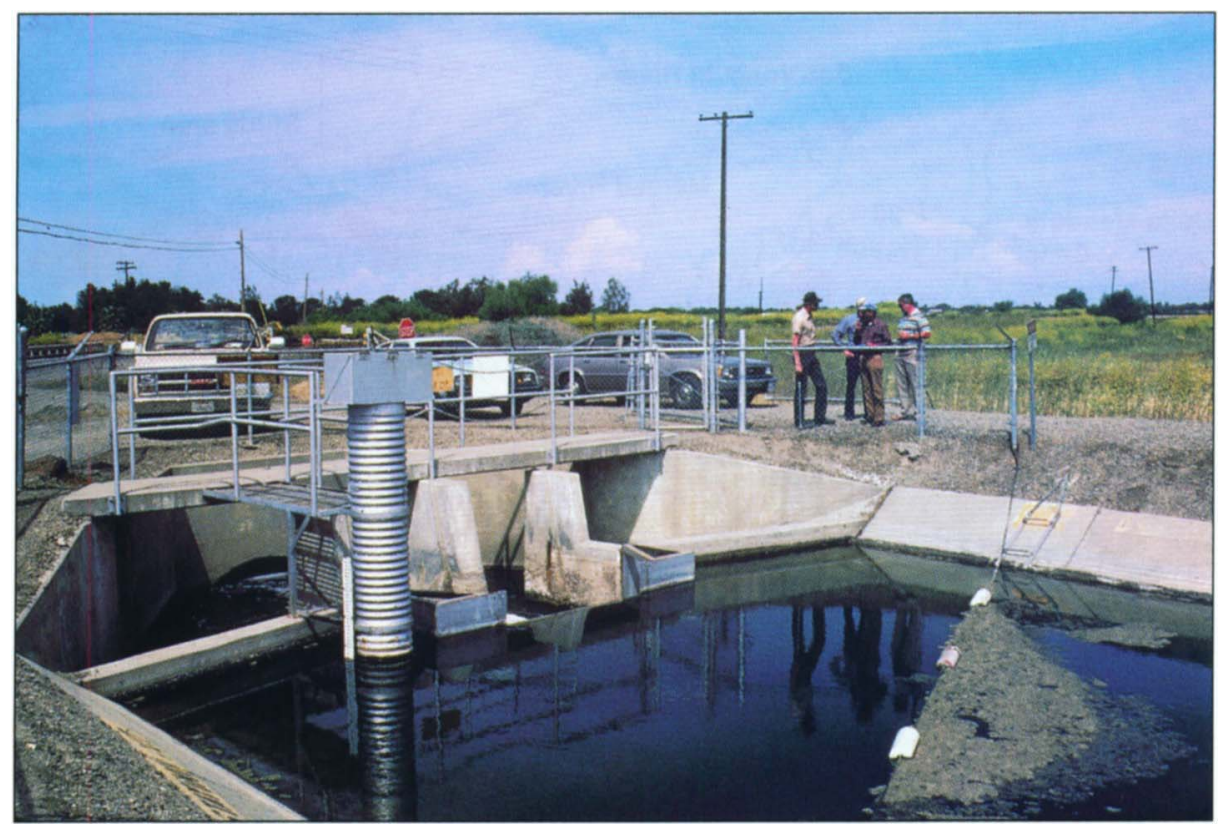

Comparisons of monthly selenium loads calculated at sites upstream and downstream allow water managers to estimate potential in-transit losses in the San Luis Drain. Flow, salinity and selenium are monitored at both sites.

nium, thereby discouraging blending of fresh water supply and seleniumcontaminated drainage water.

The need for the project became acute with the passage of time as new wetlands were acquired under the cooperative State-Federal San Joaquin Basin Action Plan, and additional wetland water supplies were made available through the Central Valley Project Improvement Act. The presence of agricultural drainage water in Grasslands conveyance facilities restricted the delivery of water to approximately 50,000 acres $(20,000 \mathrm{ha})$ of state, federal and private wetlands in 1995.

Isolating the drainage water in a single concrete-lined channel provides a more accurate accounting of salt and selenium loads than was possible with previous monitoring stations. More accurate estimates of flow and loading of salt and selenium have helped the agricultural water districts implement their drainage management strategies, and has stimulated interest in a realtime drainage monitoring and management system. Drainage reduction coupled with successful real-time drainage management will improve water quality in the San Joaquin River during periods of low assimilative capacity and will lead to compliance with California Regional Water Qual- ity Control Board (Regional Board) objectives for selenium and boron at the Crows Landing compliance point, which is located below the Merced River on the main stem of the San Joaquin River.

\section{Oversight Committee}

The agricultural water districts formed a Regional Drainage Entity to ensure legal, institutional and managerial capability to regulate drainage discharges as necessary to meet waterquality objectives and appropriate drainage reduction goals. The Activity Agreement called for development and implementation of a long-term Regional Drainage Management Plan. The agreement also called for the appointment of a Regional Drainage Coordinator, who is responsible for implementing regional actions to achieve load reductions and any other requirements for the project.

An Oversight Committee was appointed, composed of agency heads from the U.S. Bureau of Reclamation, U.S. Fish and Wildlife Service, U.S. Environmental Protection Agency, California Department of Fish and Game and the Regional Water Quality Control Board. The Oversight Committee reviews operation of the project, including attainment of selenium load reduction goals, improvements in compliance with water-quality objectives in the San Joaquin River, and adherence to the project monitoring and quality assurance/quality control plans. The committee was authorized to make recommendations to the project participants regarding all aspects of the project, including modifications to project operation, appropriate mitigative actions, extension of the use agreement after 2 years and termination of the agreement if necessary. The committee also determines the occurrence and extent of load exceedences, the drainage incentive fees that are payable, and actions or programs to be funded with the incentive fees.

The fee schedule was developed to provide monetary incentives for the phased reduction of selenium loads over 5 years. Fees can be adjusted downward, but only in the event and to the extent that the draining entities collectively demonstrate that unforeseeable and uncontrolled events caused the exceedence. The standard of "unforeseeable and uncontrollable events" is intended to deal with exceedences, for example, caused by flooding of selenium-laden coastal streams entering the drainage system such as occurred in March 1995. Annual exceedences of selenium load values by more than $20 \%$ can result in termination of the project.

\section{Compliance monitoring program}

We developed a comprehensive compliance monitoring program to monitor project impacts on flow, water quality, sediments and biota. Historical biological data, including past monitoring sites and data sets, were identified and reviewed for their usefulness in describing baseline or preproject conditions. Existing monitoring programs were considered in two categories: (1) primary monitoring sites/data that provide the basic, minimally required information to fulfill the needs and environmental commitments for the project; and (2) secondary monitoring sites/data that provide supplemental information and that are included in project analysis and reporting. Sediment, water-quality and biological monitoring are conducted at 
primary sampling locations in the Grasslands Bypass, in Mud Slough North, in the San Joaquin River and in a seasonal backwater area adjacent to Mud Slough. Salt Slough is monitored to document environmental improvements anticipated from the proposed project. Water-quality samples are also taken to document environmental improvements in the North and South Grassland Water District channels.

The sediment, biological and waterquality monitoring programs were developed, in consultation with state and federal resource and regulatory agencies, to complement ongoing and proposed environmental monitoring activities in the area of Mud and Salt sloughs. To the extent possible, we integrated existing monitoring efforts into the monitoring program for the project to avoid duplication of effort, to obtain maximum utilization of scientific expertise and to develop the most cost-effective monitoring program possible.

The purpose of the sediment-monitoring program is to observe patterns of sediment deposition and erosion in the San Luis Drain and in Mud and Salt sloughs and to assess changes in the selenium inventory in these sediments. This includes an annual survey of selenium volume in the San Luis Drain and intensive sampling of sediment selenium concentrations at three depth increments of the bed sediments (0 to $3 \mathrm{~cm} ; 3$ to $8 \mathrm{~cm}$; whole core sample) in four designated reaches (12 locations). The program also includes quarterly sampling of sediment selenium at two locations in the San Luis Drain and in Mud and Salt sloughs.

Sediment selenium concentrations are anticipated to increase in Mud Slough as a result of increased selenium concentration and loading, and to decrease in Salt Slough, which no longer conveys selenium-contaminated agricultural drainage.

The biological and toxicity monitoring programs provide a framework to assess possible significant impacts of the project's drainage water on key components of the Mud Slough aquatic community. Aquatic foodchain plants and animals are being analyzed for potential effects on fish or wildlife resources, and edible portions (fillets) of game fish are analyzed to assess risks to people who eat fish from the sloughs or river in the vicinity of the proposed project area. The fish and wildlife food-chain sampling includes representative plants, invertebrates and fish. Sampling efforts are greatest during spring and summer because fish and wildlife species are most sensitive to the adverse effects of selenium during the reproductive season (that is, eggs and young animals). Toxicity testing helps to determine

TABLE 1. Monthly total and annual selenium load targets compared for the 5-year life of the interim project. The assimilative capacity of the San Joaquin River is based on the $\mathbf{5}$ ppb selenium objective at Crows Landing.

\begin{tabular}{|c|c|c|c|c|c|}
\hline & Year 1 & Year 2 & Year 3 & Year 4 & Year 5 \\
\hline \multicolumn{6}{|c|}{ 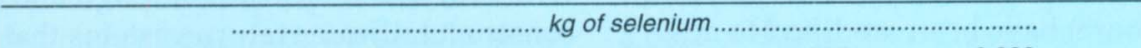 } \\
\hline \multirow{2}{*}{$\begin{array}{l}\text { 12-month total } \\
\text { Annual load }\end{array}$} & 3,225 & 3,225 & 3,097 & 2,967 & 2,839 \\
\hline & 3,000 & 3,000 & 2,876 & 2,725 & 2,573 \\
\hline \multicolumn{6}{|c|}{$\begin{array}{l}\text { * Note that the 12-month total is higher than the annual load target because the monthly targets for Septem- } \\
\text { ber through December have been adjusted to allow more selenium load to be discharged during those } \\
\text { months when assimilative capacity in the San Joaquin River is highest and to allow for variations in winter } \\
\text { rainfall. }\end{array}$} \\
\hline \multicolumn{6}{|c|}{$\begin{array}{l}\text { TABLE 2. Matrix of the incentive fee system for exceeding annual selenium targets as measured at } \\
\text { the compliance point on the San Luis Drain. Each year the allowable selenium targets are adjusted } \\
\text { downward and the maximum penalties are increased to } \$ 250,000 \text { for both annual and monthly } \\
\text { exceedence of the target selenium loads. }\end{array}$} \\
\hline \multirow[b]{2}{*}{ Year } & \multicolumn{5}{|c|}{ Percent exceedence of annual selenium target } \\
\hline & $0.1-5.0 \%$ & $5.1-10.0 \%$ & $10.1-15.0 \%$ & $15.1-20.0 \%$ & $>20 \%$ \\
\hline & \multirow{6}{*}{$\begin{array}{r}25,000 \\
44,000 \\
63,000 \\
81,000 \\
100,000\end{array}$} & ......... & $\ldots \ldots . . . .$. & ...................... & ............. \\
\hline 1 & & 50,000 & 75,000 & 100,000 & 100,000 \\
\hline 2 & & 79,000 & 115,000 & 150,000 & 150,000 \\
\hline 3 & & 92,000 & 121,000 & 150,000 & 150,000 \\
\hline 4 & & 121,000 & 160,000 & 200,000 & 200,000 \\
\hline 5 & & 150,000 & 200,000 & 250,000 & 250,000 \\
\hline
\end{tabular}

whether direct exposure of test organisms to water at selected locations causes toxicity. Short-term chronic toxicity testing is performed quarterly on water samples from the sampling sites in the San Luis Drain, Mud Slough and Salt Slough. For each test, 24-hour composite samples of water are collected from the sampling location and transported to a laboratory and tested for toxicity.

The purpose of the water-quality monitoring program is to determine variations in water-quality parameters as influenced by seasonal fluctuations in hydrologic conditions and agricultural drainage operations. Routine water-quality monitoring is complemented on a quarterly basis by additional chemical analyses for an expanded list of chemical constituents present in agricultural drainage water which, in addition to selenium and boron, includes major ions (calcium, potassium, magnesium, sodium, chloride, bicarbonate and sulfate), total alkalinity, total hardness, total dissolved solids and $\mathrm{pH}$. Those constituents are considered significant indicators of water quality and could affect toxicity of other elements or cause direct toxicity.

A Quality Assurance Project Plan was developed for the project by the U.S. Bureau of Reclamation (USBR 1996), which follows EPA's 16-element protocol. This plan includes the protocols for both field and laboratory procedures used by Reclamation, Fish and Wildlife Service, Department of Fish and Game and the California Regional Water Quality Control Board.

\section{Unresolved scientific questions}

Even though researchers have been studying selenium drainage hydrology and chemistry for over a decade, many unresolved scientific questions remain. The Grasslands Bypass Project offers a unique opportunity to help resolve some of those scientific issues.

Sediments. Previous use of the San Luis Drain was responsible for much of the accumulated sediment upstream and downstream of the 18 check structures along the 28 -miles $(45 \mathrm{~km}$ ) drain alignment. The prohibitive cost of removing and transporting the approxi- 


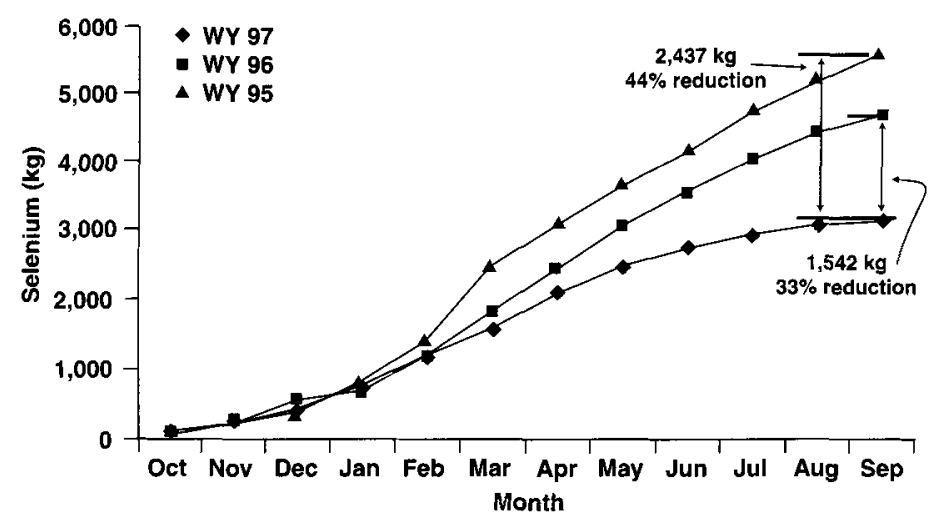

Fig. 4. Cumulative sum of selenium loads at sites PE-14 and FC-5 for water years 1995-1997.

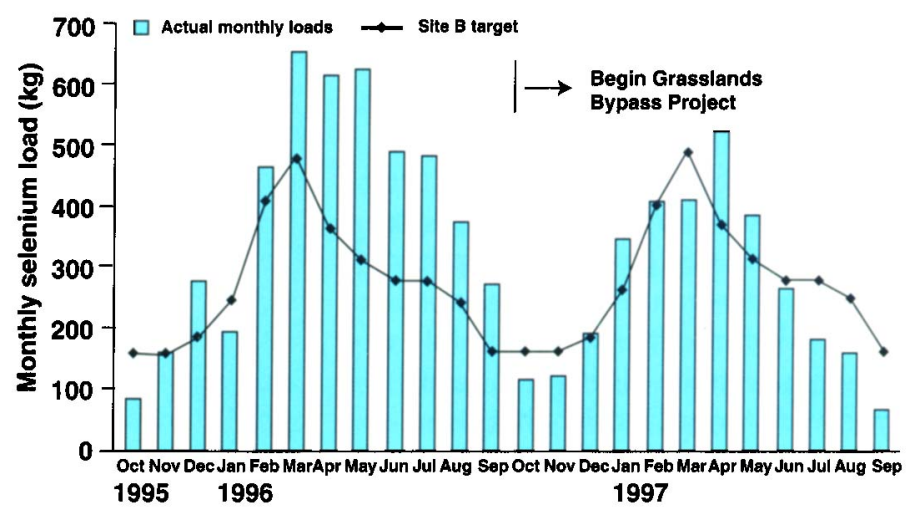

Fig. 5. Selenium loads at sites PE-14 and FC-5 for past 24 months compared to monthly selenium load targets at Site B. mately 1.9 million cubic feet $(55,000$ cubic meters) of sediment - estimated at between $\$ 1.1$ million and $\$ 3.4$ million - led to the decision to leave the sediments in place. These accumulated sediments are a potential source of selenium. If selenium in the sediments was mobilized and reintroduced into the water column, it would reduce the allowable selenium load from the project area. Under normal operations, flows of less than $1 \mathrm{ft} /$ second $(0.3 \mathrm{~m} / \mathrm{s})$ per second appear to be slow enough to prevent resuspension of bed sediments. In the event that the drain behaves as a selenium sink, there is concern that concentrations remain below the hazardous materials concentration of 100 ppm (wet weight basis).

Natural system bioremediation. Average annual losses of selenium of approximately $25 \%$ (with a wider range of monthly values) were observed from 1985 to 1996 between the monitoring sites south of the Grassland Water District and the monitoring sites located in Mud and Salt sloughs. The advent of seasonal wetland drainage in the spring, and fall water deliveries in the fall, made it more difficult to separate natural system bioremediation from the pond drainage releases and water diversions during these periods. Techniques for enhancing natural processes of selenium volatilization to the atmosphere or immobilization in the sediments would enhance the ability of the agricultural water districts to meet selenium load objectives.
Upslope contribution to drainage. Relic stream channels, long since filled by natural evolution of the alluvial fans or more recently by cultivation, are suspected of providing a hydraulic connection between the Panoche Creek alluvial fan and downslope drains. This is evident in a number of fallowed fields where tile drains flow even though neither those fields nor adjacent fields are irrigated. Managing drainage discharge is further complicated during the wet season, when ephemeral flows from the 380-squaremile watershed served by Panoche Creek recharge the alluvial fan.

\section{On-farm actions}

To meet selenium load targets, a series of innovations have been made at the farm level in the past 12 months, and irrigation practices (many of which have been in place for 40 years or more) have been modified to accommodate new management constraints and objectives.

Real-time flow and water-quality monitoring. In the first few months of the project, continuous flow meters were installed at each of the main discharge points. Daily selenium samples have been taken at district outlets and in the San Luis Drain to develop a database of load contributions from various sources and to verify the data generated by the compliance monitoring program. Radio and telephone telemetry systems have been installed at a few locations, allowing real-time monitoring of the district's contribu- tion to overall drainage flow. Water meters were retrofitted on drainage sumps and discharge points in each district to estimate the drainage flow contribution from each source and the mass contribution to each district's selenium load. With this knowledge, individual water districts have developed load targets for individual farmers in terms of allowable monthly flows. Flow is more easily measured at the farm level and less expensive than selenium analysis, which typically takes more than a week to complete in a contract laboratory and costs about $\$ 20$ per sample.

Irrigation and drainage system. One of the first actions taken by the Grasslands Basin water districts was to mandate a policy of nonacceptance of tailwater return flows in the districtowned canals. These districts worked with individual farmers to design and construct tailwater return systems that blend tailwater returns with surface water deliveries. Drainage tile systems were also retrofitted to allow control. In the case of tile systems that discharged to sumps, the sump pump control sensor was raised so that it would turn on only when water tables in the field approached an approximate 5-foot minimum depth to groundwater target. This was assessed through the construction of field water-level indicators, color-coded floating risers that protrude from the monitoring wells observable from the roadside. When water levels are sufficiently high to affect crop roots, the red por- 


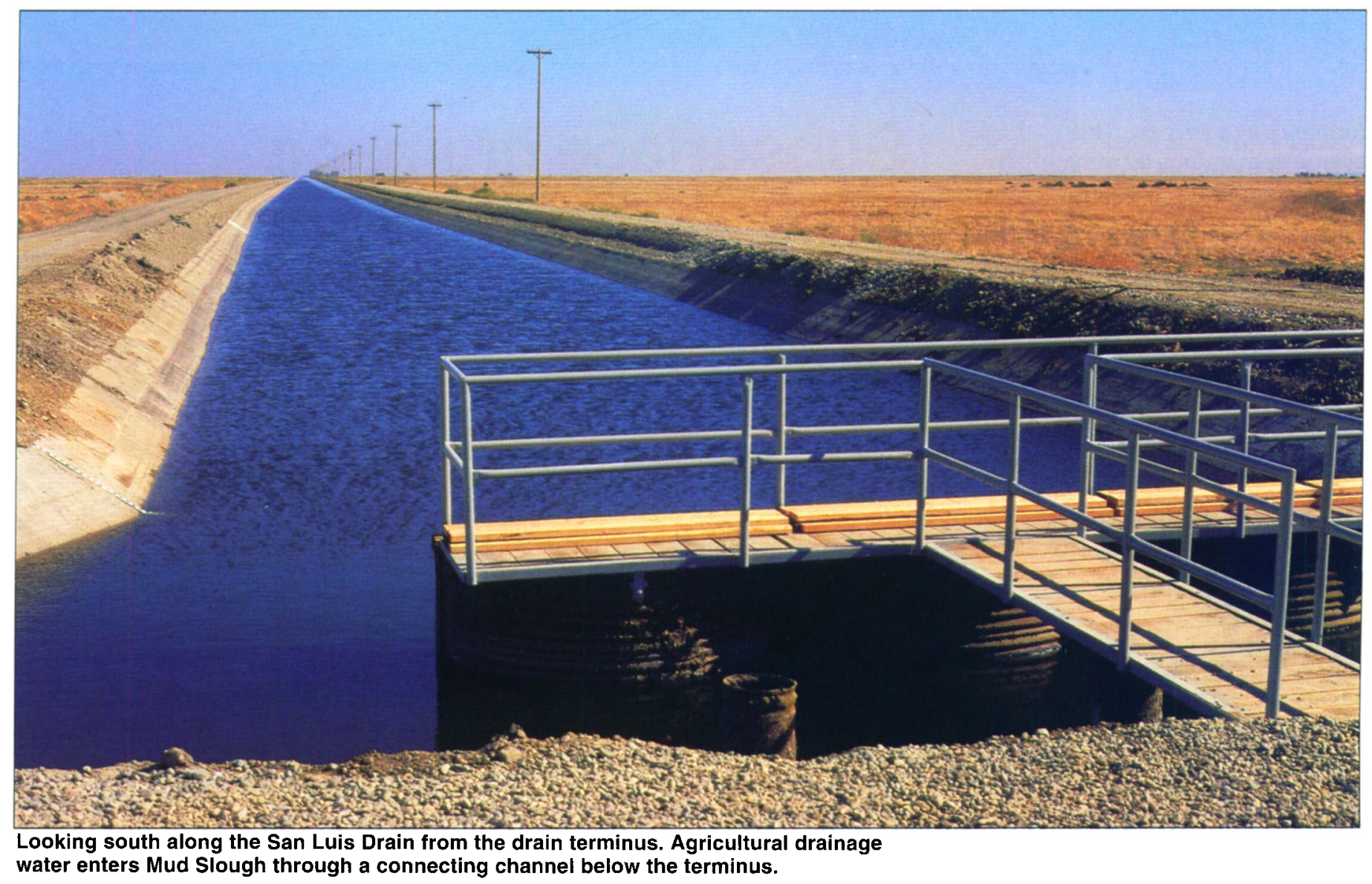

tion of the riser is visible. In the case of drains that discharge directly to open ditches, the main line was cut and a weir control structure installed to help to store more drainage water beneath each field prior to discharge to the district's drainage system.

Some water districts have encouraged drainage recycling by asking farmers to sign an interim drainage reduction agreement whereby the farmers are required to blend subsurface drainage and surface water deliveries to achieve an irrigation supply water quality of greater than 800 ppm TDS between the dates of June 30 and Sept. 30. The water districts have installed plumbing to perform this blending for the farmers in some areas. This agreement also allows the water district to cycle the operation of sump pumps to help meet monthly selenium load objectives. Knowing which sumps produce the highest selenium concentrations and selenium loads gives the water districts some flexibility toward management of drainage in real time. This policy has helped reduce selenium load by $33 \%$ and $44 \%$ as mea- sured at monitoring sites PE-14 and FC-5 for water year 1997 compared to the same periods in water years 1995 and 1996. Sites PE-14 and FC-5 measure most of the subsurface drainage generated in the project area prior to discharge into the San Luis Drain (fig. 4).

Economic incentives. A policy of tiered pricing for water deliveries has been in place for several years in the water districts and is being updated as a part of this project. This program provides irrigation water equivalent to average evapotranspiration requirements at a base rate and sells water above this basic need at increased cost. An additional water district policy, implementing a separate tiered pricing structure for preirrigation, addresses the propensity for lower on-farm irrigation efficiencies at the beginning of the irrigation season.

\section{Reduced selenium loads}

Figure 4 shows the success with which the Grasslands Area farmers have reduced selenium loads discharged from the project area. This fig- ure compares cumulative plots of selenium loads for the first year of the project (1997) and the two previous water years (1995 and 1996). Although selenium load targets were exceeded in January, February and April in the first year of the project, this was not unexpected owing to the atypical distribution of rainfall. The selenium load targets were based on mean selenium loads over a 9-year period - water years 1985-1994. None of those years produced record floods in January followed by unusually dry months in March and April. Figure 4 shows that despite the adversities of weather and market forces, a $33 \%$ to $44 \%$ reduction has been achieved. In figure 5 , the monthly selenium loads are shown relative to the monthly selenium load targets at Site B for the past 24 months (water years 1996 and 1997). The reduction in selenium load discharges during the spring and summer months (March through August) is significant.

Although the annual selenium load target was exceeded by approximately $7 \%$ in this first year of the project, the participants generally regard this per- 
formance as a success. This year has been a tremendous learning experience for water districts and farmers alike. The drainage incentive fee imposed on the Grasslands Area farmers for the selenium load overage will be placed in an account. The funds will be directed to projects that will help further reduce selenium drainage.

A unique feature of the Grasslands Bypass Project is the spirit of cooperation between water districts in this novel program. Rather than attempting to legally define each water district's share of the collective selenium discharge target load, the participants have chosen to work as one unit in meeting goals, allowing participating water districts to strive to implement best management practices at their own pace. The advances made in the past 12 months have been an intensive learning experience for water districts and individual growers alike as they seek ways to develop sustainable agronomic techniques that meet environmental policy goals and waterquality objectives for the San Joaquin River.

N.W.T. Quinn is Staff Geological Scientist, Lawrence Berkeley National Laboratory, and Water Resources Engineer, U.S. Bureau of Reclamation, Sacramento; J.C. McGahan is Principal Engineer, Summers Engineering Inc., Hanford; and M.L. Delamore is Chief Drainage Section, U.S. Bureau of Reclamation, Fresno.

\section{Further reading}

Quinn NWT. 1995. A compliance monitoring program for use and operation of the Grasslands Bypass for drainage conveyance in the western San Joaquin Valley. Lawrence Berkeley National Laboratory Topical Report, LBNL-39052, Berkeley, CA 94720.

Quinn NWT, Chen CW, Grober LF, et al 1997. Real-time management of water quality in the San Joaquin River. Cal Ag 51(5):14-20.

Summers Engineering Inc. 1997. Summary of Grassland Basin Drainers Drainage Reduction Activities. Meeting package for Grasslands Bypass project tour.

USBR. 1996. Proposed monitoring program for use and operation of the Grasslands Bypass to remove agricultural drainage from Grassland Water District channels. Sacramento, CA.

\title{
Subsurface drainage systems have little impact on water tables, salinity of clay soils
}

\author{
Mark E. Grismer $\square \quad$ Khaled M. Bali
}

Subsurface drainage systems are traditionally installed in agricultural fields to control waterlogging (high water tables) and excess salinity affecting the crop root zone. However, in many clay fields of the Imperial Valley underlain by shallow fine-sand aquifers, the drains may be ineffective and provide limited relief for the root zone. After extensive work considering soil-water flow paths in a particular field at the UC Desert Research and Extension Center (DREC), we plugged whole-field drainage systems, then evaluated the impact on water-table levels and soil salinity during a 3-year period. We found that the shallow fine-sand aquifer underlying the $D R E C$, originally identified in the 1950s, combined with the Imperial Irrigation District deep-ditch system, provided sufficient drainage relief for several areas of the DREC to successfully grow a variety of crops. Given the ineffectiveness of subsurface drainage systems in three different fields that had soil characteristics similar to more than half the Imperial Valley fields we expect that in many parts of the valley, augmentation of subsurface drainage systems through "splitting" the lateral drainline spacing may not be warranted. Indeed, efforts to reduce the salinity of heavier soils on the DREC, or elsewhere in the valley, may be better directed at improving water penetration and leaching of soils through deep ripping or other cultivation/mulching methods, rather than expending resources on improving the subsurface drainage system.

Subsurface drainage systems are traditionally installed in agricultural fields to control waterlogging (high water tables) and excess salinity affecting the crop root zone. The conceptual basis for such systems is simply to provide an artificial "outlet" for the excess water and salts in the soil resulting from regular irrigation (or from rainfall in humid areas). Although proper identification of the source of the excess water and salinity is important to the design of these systems, in many arid regions that source is assumed to be (and often is) excess irrigation recharge resulting from less-than-perfect application efficiency and distribution uniformity. In some cases, however, a more detailed field investigation may be appropriate to identify other possible sources of excess water and salinity.

We have been investigating the performance of subsurface drainage systems at the UC Desert Research and Extension Center (DREC) for the past three decades to determine their value relative to control of shallow groundwater levels and root-zone soil salinity (Grismer et al. 1988). In the cracking, or heavy clay, soils found on the DREC and in over $40 \%$ of the valley, the drains are relatively ineffective in 